\title{
PENGEMBANGAN SISTEM INFORMASI PENILAIAN KINERJA KARYAWAN MENGGUNAKAN METODE AHP DAN TOPSIS
}

\author{
FahmyAinun Nazilla ${ }^{1}$, Nurudin Santoso ${ }^{2}$, Imam Fahrur Rozi ${ }^{3}$ \\ Program Studi Teknik Informatika, Jurusan Teknologi Informasi, Politeknik Negeri Malang \\ JL. Soekarno-Hatta No. 9 Malang 65141, Indonesia \\ 1ahmy.nazilla@gmail.com, ${ }^{2}$ nurudin@polinema.ac.id, ${ }^{3}$ imam.rozi@polinema.ac.id
}

\begin{abstract}
Abstrak
Penilaian kinerja karyawan merupakan aspek penting dalam manajemen sumber daya manusia yang efektif. Namun pada kenyataannya penilaian kinerja karyawan bagian produksi pada PT Pendawa Polysindo Perkasa belum cukup optimal karena belum adanya pembobotan terhadap kriteria penilaian dan untuk menentukan karyawan terbaik masih dinilai secara subyektif.

Pada penelitian ini dibuat sistem informasi untuk membantu pembobotan kriteria dan perankingan karyawan guna memperoleh karyawan terbaik dengan mengurangi tingkat subyektifitas penilaian. Kelebihan Analytical Hierarchy Process (AHP) adalah berdasar pada matriks perbandingan berpasangan dan melakukan analisis konsistensi. Sedangkan metode Technique For Others Reference By Similarity To Ideal Solution (TOPSIS) memiliki konsep dimana alternatif terpilih yang terbaik tidak hanya memiliki jarak terpendek dari solusi ideal positif, tetapi juga memiliki jarak terpanjang dari solusi ideal negatif. Setelah dilakukan pengembangan sistem informasi, kemudian penelitiakan membandingkan tiga metode yaitu gabungan metode AHP dan TOPSIS, metode AHP dan metode TOPSIS.

Hasil pengujian metode AHP dan TOPSIS yang dilakukan dengan membandingkan hasil pengujian sistem dan pengujian manual perusahaan diperoleh tingkat akurasi $80 \%$ dari 10 sampel data penilaian karyawan yang diuji. Untuk perbandingan pengujian manual perusahaan dengan metode AHP diperoleh tingkat akurasi $50 \%$, sedangkan dengan metode TOPSIS $60 \%$.
\end{abstract}

Kata Kunci: sistem pendukung keputusan, karyawan, AHP, TOPSIS

\section{Pendahuluan}

Menurut Mursidi (2009), sumber daya manusia merupakan faktor kendali yang dapat menentukan keberlangsungan sebuah perusahaan. Perusahaan dituntut untuk dapat selalu mempertahankan dan mengembangkan sumber daya manusia yang berkualitas guna menghadapi segala macam kemungkinan perubahan yang akan terjadi.

Penilaian kinerja adalah proses mengevaluasi dan menilai prestasi kerja karyawan. Kegiatan ini dapat memperbaiki keputusankeputusan pada bagian produksi dan memberikan umpan balik kepada para karyawan tentang pelaksanaan kerja mereka. Penilaian kinerja merupakan aspek penting dalam manajemen sumber daya manusia yang efektif dan dapat membantu perusahaan untuk mengetahui kondisi kerja dari para karyawannya. Penilaian kinerja karyawan yang dilakukan oleh PT Pendawa Polysindo Perkasa belum cukup optimal karena belum adanya pembobotan terhadap kriteria penilaian dan dan untuk menentukan karyawan terbaik masih dinilai secara subyektif.

Sistem Pendukung Keputusan dengan metode Analytical Hierarchy Process (AHP) dapat menjadi solusi dalam melakukan pembobotan kriteria kinerja karyawan. Peralatan utama AHP adalah sebuah hierarki fungsional dengan input utamanya persepsi manusia. Keberadaan hierarki memungkinkan dipecahnya masalah kompleks atau tidak terstruktur dalam sub-sub masalah, lalu menyusunnya menjadi suatu bentuk hierarki.

Metode Technique For Others Reference By Similarity To Ideal Solution (TOPSIS) memiliki konsep dimana alternatif terpilih yang terbaik tidak hanya memiliki jarak terpendek dari solusi ideal positif, tetapi juga memiliki jarak terpanjang dari solusi ideal negatif. Dengan kata lain alternatif yang memiliki nilai yang lebih besar itulah yang lebih baik untuk dipilih.

Setelah dilakukan pengembangan sistem informasi, kemudian penelitiakan membandingkan tiga metode yaitu gabungan metode AHP dan TOPSIS, metode AHP danmetode TOPSIS.

\section{Metode AHP dan TOPSIS}

\subsection{Konsep Dasar AHP}

Metode Analytical Hierarchy Process (AHP) dikembangkan awal tahun 1970-an oleh Thomas L. Saaty, dari Universitas Pittsburg. Model AHP memakai persepsi manusia yang dianggap 
'expert' sebagai input utamanya. Kata 'expert' mengacu pada orang yang mengerti benar permasalahan yang dilakukan, merasakan akibat suatu masalah atau punya kepentingan terhadap masalah tersebut.

Dalam memecahkan persoalan dengan analisa berpikir logis pada AHP ini, ada tiga prinsip AHP yang perlu diperhatikan, yaitu:
a. Menyusun hirarki
b. Menentukan prioritas
c. Konsistensi logis

Kelebihan AHP diantaranya adalah AHP berdasar pada matriks perbandingan berpasangan dan melakukan analisis konsistensi.

Dalam menyelesaikan masalah pengambilan keputusan, ada beberapa tahapan metode AHP yang dilakukan antara lain:

1) Penyusunan matriks perbandingan berpasangan yang merepresentasikan tingkat kepentingan antar kriteria berdasarkan skala preferensi AHP.

Tabel 2.1 Skala preferensi AHP

\begin{tabular}{|c|l|}
\hline Intensitas & \multicolumn{1}{|c|}{ Keterangan } \\
\hline 1 & Kedua elemen sama pentingnya \\
\hline 3 & $\begin{array}{l}\text { Elemen yang satu sedikit lebih } \\
\text { penting daripada elemen yang lainnya }\end{array}$ \\
\hline 5 & $\begin{array}{l}\text { Elemen yang satu lebih penting } \\
\text { daripada yang lainnya }\end{array}$ \\
\hline 7 & $\begin{array}{l}\text { Satu elemen jelas lebih mutlak } \\
\text { penting daripada elemen lainnya }\end{array}$ \\
\hline 9 & $\begin{array}{l}\text { Satu elemen mutlak penting daripada } \\
\text { elemen lainnya }\end{array}$ \\
\hline $2,4,6,8$ & $\begin{array}{l}\text { Nilai-nilai dua nilai pertimbangan- } \\
\text { pertimbangan yang berdekatan }\end{array}$ \\
\hline
\end{tabular}

Sumber: Saaty, 1986

2) Normalisasi matriks keputusan.

3) Analisis konsistensi. Menghitung indeks konsistensi (CI) dengan persamaan

$$
C I=\frac{\lambda-n}{n-1}
$$

Analisis konsistensi lain yang juga harus dihitung adalah rasio konsistensi (CR).

$$
C R=\frac{C I}{R I}
$$

Jika $\mathrm{CR} \leq 0,10$ maka matriks perbandingan berpasangan konsisten, sehingga bobot yang diberikan dapat digunakan pada perankingan alternatif dalam metode TOPSIS.

\subsection{Konsep Dasar TOPSIS}

TOPSIS didasarkan pada konsep dimana alternatif terpilih yang terbaik tidak hanya memiliki jarak terpendek dari solusi ideal positif, tetapi juga memiliki jarak terpanjang dari solusi ideal negatif (Hwang, 1981) dan (Zeleny, 1982).
Metode TOPSIS memiliki beberapa kelebihan, yaitu:

a. konsepnya sederhana dan mudah dipahami

b. komputasinya efisienn

c. memiliki kemampuan untuk mengukur kinerjarelatif dari alternatif-alternatif keputusan dalambentuk matematis yang sederhana.

Langkah-langah penyelesaian masalah menggunakan metode TOPSIS, antara lain:

1) Menentukan matriks keputusan yang ternormalisasi

2) Menghitung perkalian bobot preferensi dengan matriks ternormalisasi

3) Menghitung matriks solusi ideal positif dan solusi ideal negatif.

4) Menghitung jarak antara nilai setiap alternatif dengan matriks solusi ideal positif dan solusi ideal negatif.

5) Mencari nilai preferensi untuk setiap alternatif.

\section{Perancangan dan Implementasi}

\subsection{Perancangan Sistem}

Perancangan sistem terdiri dari use case, flowchartperhitungan metode AHP dan TOPSIS, data kriteria dan pembobotan kriteria.

\subsubsection{Flowchart Perhitungan AHP dan TOPSIS}

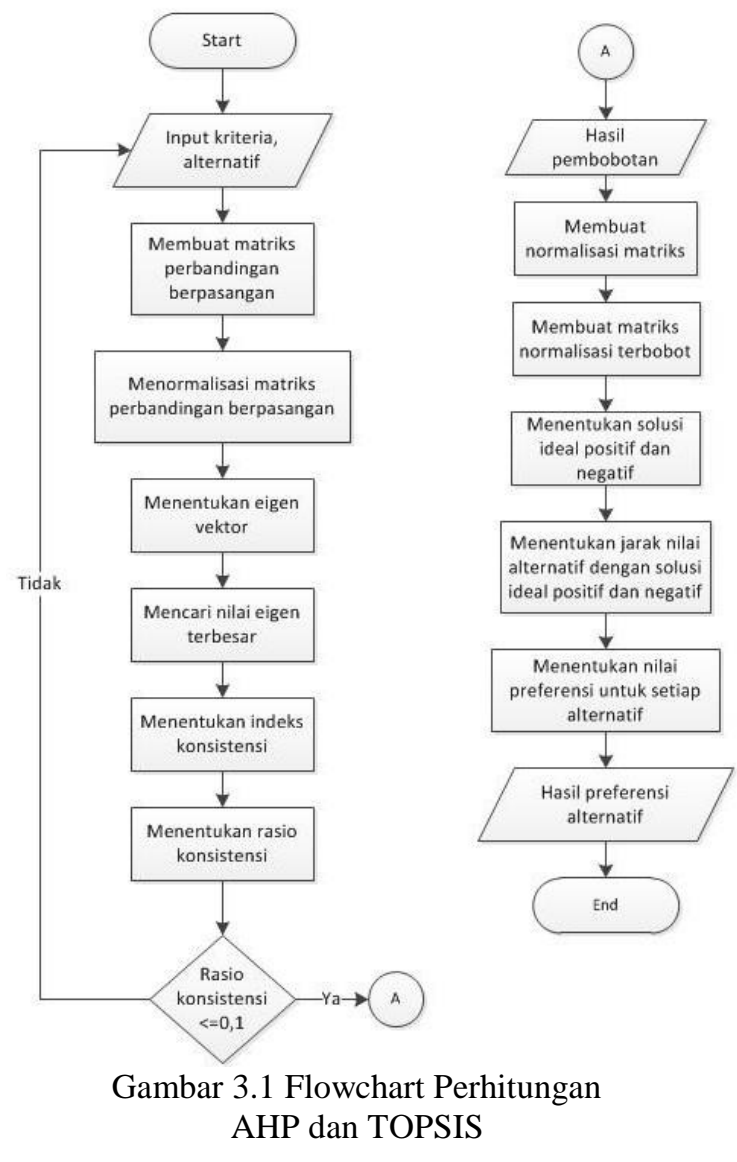




\subsubsection{Use Case}

Use case diagram merupakan pemodelan untuk kelakuan (behavior) sistem yang akan dibuat (Rosa A.S., 2013).

Sistem yang akan dibangun adalah Sistem Informasi Penilaian Kinerja Karyawan. User pada sistem ini ada 3, yaitu:

1) Manajer, adalah pengguna yang berperan penting dalam melakukan pembobotan kriteria penilaian dan melihat laporan.

2) Kepala Bagian, adalah orang yang mempunyai hak akses untuk menilai karyawan.

3) Admin, adalah orang yang bertanggung jawab dalam mengelola data karyawan.

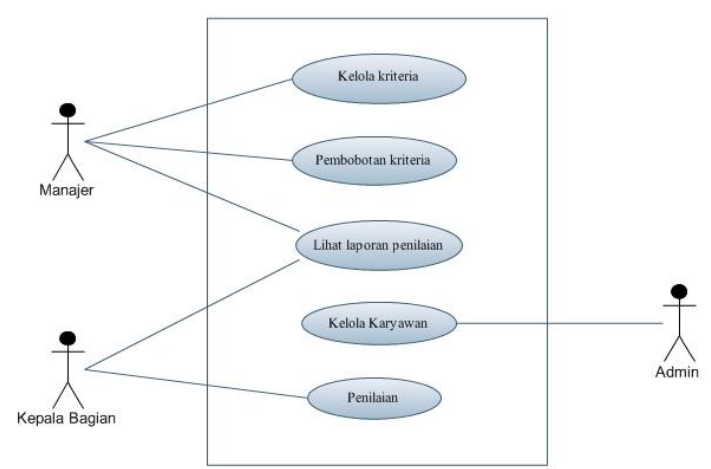

Gambar 3.2 Use Case

\subsubsection{Kriteria}

Adapun kriteria-kriteria yang digunakan dalam penilaian kinerja karyawan yaitu:

a. Disiplin

Kriteria disiplin antara lain mematuhi aturan, datang tepat waktu dan menyelesaikan tugas sesuai dengan waktu yang ditentukan.

b. Tanggung Jawab

Kriteria tanggung jawab antara lain menyelesaikan tugas sesuai target dan menerima resiko dari tindakan yang dilakukan.

c. Jujur

Kriteria jujur antara lain melaporkan dengan benar jika terjadi masalah dalam produksi,tidak mengambil barang yang bukan miliknya serta mengembalikan kepada yang berhak apabila menemukan barang.

d. Sopan

Kriteria sopan adalah tutur kata dan tingkah laku yang baik dalam bergaul yaitu menghormati atasan dan menghargai sesama.

e. Absensi setiap hari.

Absensi adalah rekap kehadiran karyawan

f. Ketrampilan

Kriteria ini adalah kriteria yang paling penting berdasarkan observasi yang dilakukan. Subkriteria Ketrampilan adalah memiliki kemampuan dan pengetahuan dalam mengolah limbah plastik, kemampuan berkomunikasi, hasil produksi memenuhi standar serta mempunyai ide atau inisiatif untuk menyelesaikan permasalahan.

g. Motivasi Diri

Kriteria motivasi diri adalah selalu berusaha bekerja dengan baik sesuai dengan minat dan kemampuan yang dimiliki.

h. Loyalitas

Kriteria loyalitas adalah mempunyai komitmen untuk bekerja pada perusahaan.

\subsubsection{Pembobotan Kriteria}

Pada Sistem Informasi Penilaian Kinerja Karyawan ini prosedur pembobotan ditentukan langsung oleh pengambil keputusan yaitu user Manajer dengan membandingkan tingkat kepentingan antar kriteria penilaian. Jumlah keseluruhan bobot kriteria dalam sistem ini adalah $100 \%$. Semakin besar nilai bobot menunjukkan semakin besarnya tingkat kepentingan kriteria dalam pengambilan keputusan.

\subsection{Implementasi}

\subsubsection{Implementasi Basis Data}

Implementasi basis data dilakukan sesuai dengan perancangan yang telah dilakukan. Basis datayang dibuat diberi nama db_spkkinerja. Pada basis data db_spkkinerjaterdapat $\overline{6}$ tabel, antaralain tb_user, tb_kriteria, tb_subkriteria, tb_karyawan, tb_nilai dan tb_ranking.

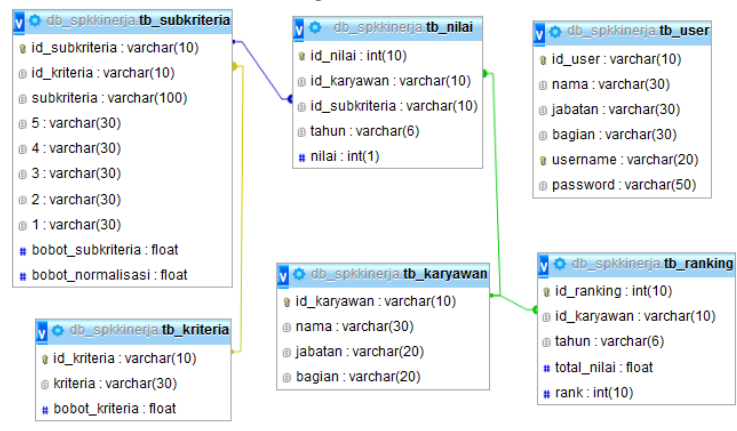

\subsubsection{Implementasi Program}

Implementasi Sistem Informasi Penilaian Kinerja Karyawan ini dilakukan dengan bahasa pemrograman PHP.

1) Halaman Perbandingan Kriteria

Merupakan halaman pertama untuk menentukan bobot penilaian yang merupakan implementasi dari metode AHP. Manajer melakukan perbandingan kriteria berdasarkan tingkat kepentingan antar kriteria. 


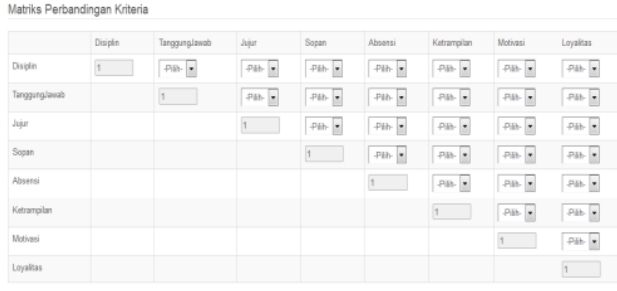

Gambar 3.3 Halaman Perbandingan Kriteria

2) Halaman Penilaian

Menggambarkan halaman untuk melakukan penilaian kinerja karyawan. terdiri dari kriteria penilaian, subkriteria dan skala penilaiannya.

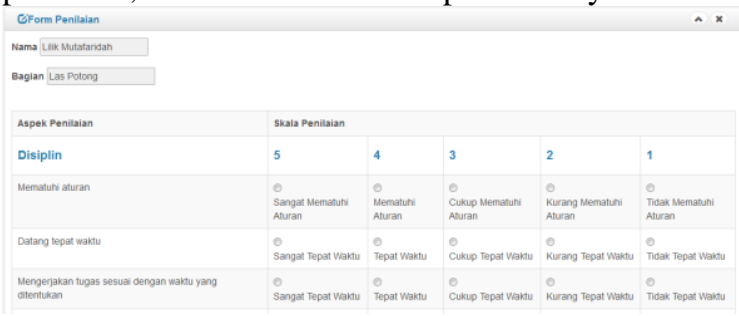

Gambar 3.4 Halaman Perhitungan TOPSIS

\section{Pengujian dan Pembahasan}

\subsection{Pengujian Validasi}

Pengujian validasi dikatakan berhasil apabila fungsi yang ada pada sistem sesuai dengan yang diharapkan pengguna. Validasi sistem merupakan kumpulan seri uji coba Black Box yang menunjukkan sesuai dengan yang diharapkan.

\subsection{Pengujian Sistem}

Pengujian ini dilakukan dengan caramenghitung ketepatan perhitungan metode dengan bantuan pendukung aplikasi Microsoft Excel. Hasil dari pengujian manual menggunakan Microsoft Excel akan dicocokan dengan hasil pengujian sistem. Pengujian sistem diantaranya yaitu pengujian perhitungan metode AHP dan pengujian perhitungan metode TOPSIS. Pada pengujian perhitungan metode AHP digunakan data kriteria penilaian sejumlah 8 data. Sedangkan pada pengujian perhitungan metode TOPSIS digunakan 5 data sampel dari alternatif karyawan yang dipilih secara acak.

\subsection{Pengujian Akurasi}

Pengujian akurasi sistem terhadap data alternatif karyawan dilakukan dengan cara membandingkan hasil perankingan sistem dengan perankingan manual dari pengambil keputusan.Sejumlah data penilaian kinerja karyawan dimasukkan dalam sistem lalu diproses menggunakan metode TOPSIS. Hasil dari sistem akan dibandingkan dengan hasil perhitungan manual perusahaan.
Tabel 4.1 Data UjiMetode AHP-TOPSIS

\begin{tabular}{|c|c|c|}
\hline $\begin{array}{c}\text { Ranking } \\
\text { AHP- } \\
\text { TOPSIS }\end{array}$ & $\begin{array}{c}\text { Ranking } \\
\text { Perusahaan }\end{array}$ & Keterangan \\
\hline 1 & 1 & Sesuai \\
\hline 6 & 6 & Sesuai \\
\hline 10 & 10 & Sesuai \\
\hline 9 & 9 & Sesuai \\
\hline 2 & 2 & Sesuai \\
\hline 8 & 8 & Sesuai \\
\hline 4 & 5 & Tidak Sesuai \\
\hline 3 & 3 & Sesuai \\
\hline 5 & 4 & Tidak Sesuai \\
\hline 7 & 7 & Sesuai \\
\hline
\end{tabular}

Tabel 4.2 Data UjiMetode AHP

\begin{tabular}{|c|c|c|}
\hline $\begin{array}{c}\text { Ranking } \\
\text { AHP }\end{array}$ & $\begin{array}{c}\text { Ranking } \\
\text { Perusahaan }\end{array}$ & Keterangan \\
\hline 1 & 1 & Sesuai \\
\hline 8 & 6 & Tidak Sesuai \\
\hline 9 & 10 & Tidak Sesuai \\
\hline 10 & 9 & Tidak Sesuai \\
\hline 2 & 2 & Sesuai \\
\hline 7 & 8 & Tidak Sesuai \\
\hline 5 & 5 & Sesuai \\
\hline 3 & 3 & Sesuai \\
\hline 4 & 4 & Sesuai \\
\hline 6 & 7 & Tidak Sesuai \\
\hline
\end{tabular}

Tabel 4.3 Data UjiMetode TOPSIS

\begin{tabular}{|c|c|c|}
\hline $\begin{array}{c}\text { Ranking } \\
\text { TOPSIS }\end{array}$ & $\begin{array}{c}\text { Ranking } \\
\text { Perusahaan }\end{array}$ & Keterangan \\
\hline 1 & 1 & Sesuai \\
\hline 6 & 6 & Sesuai \\
\hline 10 & 10 & Sesuai \\
\hline 9 & 9 & Sesuai \\
\hline 3 & 2 & Tidak Sesuai \\
\hline 8 & 8 & Sesuai \\
\hline 4 & 5 & Tidak Sesuai \\
\hline 2 & 3 & Tidak Sesuai \\
\hline 5 & 4 & Tidak Sesuai \\
\hline 7 & 7 & Sesuai \\
\hline
\end{tabular}

\subsection{Pembahasan}

Dari percobaan pengujian sistem didapatkan kesimpulan bahwa tingkat keberhasilan pembuatansistem ini telah berhasil dilakukan setelah melakukan implementasi pada sistem penilaian kinerja karyawan dengan menerapkan metode AHP dan TOPSIS menghasilkan hasil yang sama dengan hasil perhitungan pengujian manual. Berikut hasil analisa pengujian sistem. 
Tabel 4.4 Analisa Pengujian Metode AHP

\begin{tabular}{|c|c|c|c|c|}
\hline Kriteria & Uji Sistem & Uji Manual & Error & $\begin{array}{c}\text { Prosentase } \\
\text { Error }\end{array}$ \\
\hline Disiplin & 0.1019 & 0,1019 & 0,000 & $0 \%$ \\
\hline $\begin{array}{c}\text { Tanggung } \\
\text { Jawab }\end{array}$ & 0.2421 & 0,2421 & 0,000 & $0 \%$ \\
\hline Jujur & 0.0795 & 0,0795 & 0,000 & $0 \%$ \\
\hline Sopan & 0.0707 & 0,0707 & 0,000 & $0 \%$ \\
\hline Absensi & 0.0394 & 0,0394 & 0,000 & $0 \%$ \\
\hline Ketrampilan & 0.2615 & 0,2615 & 0,000 & $0 \%$ \\
\hline Motivasi Diri & 0.1829 & 0,1829 & 0,000 & $0 \%$ \\
\hline Loyalitas & 0.022 & 0,022 & 0,000 & $0 \%$ \\
\hline \multicolumn{5}{|c|}{ Rata-rata Error } \\
\hline
\end{tabular}

Tabel 4.5 Analisa Pengujian Metode TOPSIS

\begin{tabular}{|c|c|c|c|c|}
\hline Karyawan & $\begin{array}{c}\text { Uji } \\
\text { Sistem }\end{array}$ & $\begin{array}{c}\text { Uji } \\
\text { Manual }\end{array}$ & Error & $\begin{array}{c}\text { Prosentase } \\
\text { Error }\end{array}$ \\
\hline Kasmaji & 0,48871 & 0,48871 & 0,000 & $0 \%$ \\
\hline Riyanto & 0,31887 & 0,31887 & 0,000 & $0 \%$ \\
\hline Sadi & 0,46887 & 0,46887 & 0,000 & $0 \%$ \\
\hline Muliadi & 0,29216 & 0,29216 & 0,000 & $0 \%$ \\
\hline Mahfud & 0,83874 & 0,83874 & 0,000 & $0 \%$ \\
\hline \multicolumn{5}{|c|}{ Rata-rata Error } \\
\hline
\end{tabular}

Berdasarkan analisa pengujian metode AHP dan TOPSIS, diperoleh rata-rata error yang sama yaitu $0 \%$. Sehingga implementasi metode AHP dan TOPSIS pada sistem informasi penilaian kinerja karyawan ini sesuai dengan yang diharapkan.

Sedangkan untuk menentukan akurasi sistem, dengan meliihat antara perbandingan dari hasil perankingan sistem dengan perankingan manual pada perusahaan yang dijelaskan pada Tabel 4.1, Tabel 4.2 danTabel 4.3, maka dapat disimpulkan bahwa dengan menguji 10 data sampelpadametode AHP-TOPSIS dihasilkan 8 jumlah data sesuai, sedangkanpadametode AHP dihasilkan 5 jumlah data sesuaidanpadametode TOPSIS dihasilkan 6 jumlah data sesuai.

Untuk tingkat keakurasian perbandingan antara perhitungan secara manual dan padaperhitunganmetode, maka dilakukan perhitungan prosentase keakuratan dari persamaan berikut:

$$
\frac{\text { Jumlah data sama }}{\text { Total data }} \times 100 \%
$$

Hasil prosentase menujukkan bahwametode AHP-TOPSIS memilikitingkatakurasi $80 \%$ dibandingkan perhitungan manual. Sedangkan metode AHP memiliki tingkat akurasi 50\% dan metode TOPSIS memiliki tingkat akurasi $60 \%$. Sehingga dapat disimpulkan bahwa perhitungan metode AHP-TOPSIS telah terimplementasi dengan cukup baik dengan akurasi $80 \%$.

\section{Kesimpulan dan Saran}

\subsection{Kesimpulan}

Berdasarkan penelitian yang dilaksanakan oleh penulis pada pengembangan sistem informasi penilaian kinerja karyawan menggunakan metode AHP dan TOPSIS, dapat ditarik kesimpulan sebagai berikut:

a. Sistem ini telah berhasil menerapkan metode AHP dan TOPSIS untuk penilaian kinerja karyawan pada PT. Pendawa Polysindo Perkasa.

b. Hasil pengujian menunjukkan bahwa perancangan sistem telah menghasilkan sistem yang dapat membantu penilaian kinerja karyawan dengan output perankingan karyawan secara otomatis dan hasil penilaian menjadi lebih obyektif.

c. Hasil pengujian akurasi dilakukan dengan membandingkan tiga metode yaitu metode gabungan AHP dan TOPSIS, metode AHP dan metode TOPSIS diperoleh akurasi tertinggi dengan metode gabungan AHP dan TOPSIS adalah $80 \%$.

\subsection{Saran}

Sistem ini masih dibuat secara sederhana, pengembangan sistem ke depannya dapat mempertimbangkan hal-hal berikut:

a. Sistem ini dapat dikembangkan menggunakan penggabungan metode lain dalam menentukan pembobotan dan perankingan.

b. Sistem ini dapat dikembangkan dengan pengambil keputusan lebih dari satu orang atau biasa disebut Group Decision Support System (GDSS). 


\section{Daftar Pustaka:}

Dessler, Gary, 1997, Manajemen Sumber Daya Manusia.Edisi ke-7, Alih bahasa, Jilid 1 \&Jilid 2, Prenhallindo, Jakarta.

Gomes, Faustino Cardoso, 1995, Manajemen Sumber Daya Manusia, Andi Offset, Yogyakarta.

Handoko, Hani, 1996, Manajemen Personalia dan Sumber Daya Manusia, BPFE, Yogyakarta.

Juliyanti, Mohammad Isa Irawandan Imam Mukhlash (2011). "Pemilihan Guru Berprestasi Menggunakan Metode AHP dan TOPSIS". Prosiding Seminar Nasional Penelitian, Pendidikan dan Penerapan MIPA, Fakultas MIPA, UniversitasNegeri Yogyakarta.

Kadir, A. 2003. Pengenalan Sistem Informasi. Yogyakarta. Andi Offset.

Kusrini. (2007). Konsep dan Aplikasi Sistem Pendukung Keputusan. Andi. Yogyakarta.

Muhammad Auliya Bachtiar (2014). "Aplikasi Penilaian Kinerja Karyawan Menggunakan Metode SMART (Simple Multi-Attribute Rating Technique)". Skripsi Mahasiswa D4 Teknik Informatika Politeknik Negeri Malang.

Mursidi. 2009. Pengaruh Pendidikan Dan Pelatihan Terhadap Kinerja Karyawan. Jurnal Teknik Industri. 10(2):120-127.

Saaty, T.L. (1993). Decision Making for Leader: The Analytical Hierarchy Process for Decision in Complex World, Prentice Hall Coy: Ltd, Pittsburgh.

Saaty, T.L. (1986). Decision Making for Leaders: The Analytic Hierarchy Process for Decisions in Complex World. University of Pittsburgh.

Siti Kholijah Ritonga (2013). "Sistem Informasi Penilaian Kinerja Karyawan Menggunakan Metode Technique for Others Reference by Similarity to Ideal Solution (TOPSIS)".

Stoner, James A.F., Freeman Edward and Daniel Gilbert, 1996, Manajemen. Alih Bahasa. Jilid 1 \& Jilid 2, Simon \& Schuster (Asia Pte. Ltd.), Jakarta.

Turban, E., Jay, E. A. 2005. Decision Support System and Inteligent System (Versi bahasa Indonesia), Edisi ke-7. Andi Offset. Yogyakarta.

Winiarti, S. dan Yuraida, U. (2009). "Aplikasi Sistem Pendukung Keputusan Penentuan Lokasi Pendirian Warnet dengan metode AHP'. Jurnal Informatika. 3 (2), 311 - 322.

Yosep Agus Pranoto, M. Aziz Muslim dan Rini Nur Hasanah (2013). "Rancang Bangun dan Analisis Decision Support Sistem Menggunakan Metode Analytical Hierarchy Process untuk Penilaian Kinerja Karyawan”. Jurnal EECCIS Vol. 7, No. 1, Juni 201

S.A., Rosa, dan Shakahudin. M. 2013. Rekayasa Perangkat Lunak Terstruktur dan Berorientasi Objek. Bandung: Informatika. 